\title{
Fibroma desmoplásico de mandíbula asociado a esclerosis tuberosa. Revisión de la literatura y presentación de un caso
}

\author{
Desmoplastic fibroma of the jaw associated with tuberous sclerosis. \\ Literature review and case report
}

\author{
M. Acosta Feria', P. Infante Cossío², D. López Vaquero', A. Carranza Carranza3 , J.L. Gutiérrez Pérez
}

Resumen: La esclerosis tuberosa es una anomalía congénita del desarrollo embrionario que se transmite de forma autosómica dominante caracterizada por la presencia por trastornos neurológicos, cutáneos o dermatológicos, y retraso mental. Se pueden afectar otros órganos y sistemas, y dar manifestaciones orofaciales. La lesión a nivel del esmalte dental constituye la lesión intraoral más frecuente. Rara vez se pueden encontrar lesiones óseas en los maxilares. El fibroma desmoplásico es un infrecuente tumor fibroso intraóseo localmente agresivo de lento crecimiento, que se asocia muy rara vez a la esclerosis tuberosa. Presentamos el caso clínico de un paciente de 33 años afecto de esclerosis tuberosa con una lesión en la mandíbula diagnosticada como fibroma desmoplásico. Se discuten los métodos diagnósticos, presentación clínica y tratamiento.

Palabras clave: Esclerosis tuberosa; Fibroma desmoplásico; Enfermedad de Bourneville; Manifestaciones orales; Mandíbula.

Recibido: 12.03 .07

Aceptado: 04.02.08
Abstract: Tuberous sclerosis is a congenital anomaly of embryonic development with an autosomal dominant inheritance. It is characterized by the presence of neurologic and dermatologic disorders and mental retardation. It can affect other organs and systems and produce orofacial manifestations. Dental enamel defects are the most frequent intraoral lesion. Bone lesions rarely occur in the upper jaw. Desmoplastic fibroma is an infrequent, slow-growing, locally aggressive intraosseous fibrous tumor that rarely is associated with tuberous sclerosis. We report the clinical case of a 33-year-old man with tuberous sclerosis and a jaw lesion diagnosed as desmoplastic fibroma. The diagnostic methods, clinical presentation, and treatment are discussed.

Key words: Tuberous sclerosis; Desmoplastic fibroma; BournevillePringle disease; Oral manifestations; Jaw.

1 Médico Residente. Servicio de Cirugía Oral y Maxilofacial.

2 Médico Adjunto. Servicio de Cirugía Oral y Maxilofacial.

3 Médico Residente. Servicio de Anatomía Patológica.

4 Jefe de Servicio. Servicio de Cirugía Oral y Maxilofacial.

Hospital Universitario Virgen del Rocío, Sevilla, España.

\section{Correspondencia:}

Pedro Infante Cossío

Servicio de Cirugía Oral y Maxilofacial

Hospital Universitario Virgen del Rocío

Avda. Manuel Siurot s/n

41013-Sevilla, España

Email: pinfante@us.es 


\section{Introducción}

La esclerosis tuberosa (ET) o enfermedad de Bourneville es una anomalía congénita del desarrollo embrionario que se transmite de forma autosómica dominante, presentando diferentes formas de expresión clínica. En la actualidad se asocia a mutaciones de los genes TSC 1 y TSC2 supresores del crecimiento tumoral. ${ }^{1}$ Se clasifica dentro de las denominadas facomatosis o anomalías del desarrollo, susceptibles de originar tumores y/o hamartomas del sistema nervioso. ${ }^{2,3}$ Se caracteriza por la formación de tumores hamartomatosos benignos, neurofibromas y angiofibromas, localizados en diferentes órganos de la economía. ${ }^{4}$ La enfermedad ocurre en el $0,1-0,6 \%$ de las personas diagnosticadas de epilepsia y retraso mental, y entre 1/30.000-50.000 personas de la población general. ${ }^{5-8}$ La prevalencia de la enfermedad se sitúa en 1 de cada 6.000 habitantes. ${ }^{7}$

La tríada clásica de la ET comprende epilepsia, retraso mental y angiofibromas faciales, frecuentemente en forma de alas de mariposa. Sin embargo, la tríada se halla en menos de un tercio de los pacientes y hasta en un $6 \%$ de los casos no se presenta ninguno de estos síntomas. En las formas incompletas o frustradas, el diagnóstico puede pasar inadvertido, por lo que debemos sospechar la enfermedad en aquellos pacientes con epilepsia junto con anormalidades cutáneas que presenten un deterioro neurológico progresivo. 2,9,10 La mayoría de los pacientes afectos de ET mueren antes de los 20 años de edad. La causa de la muerte generalmente se produce por estatus epiléptico, neumonía, caquexia o infarto agudo de miocardio. Existen formas paucisintomáticas o incompletas de la enfermedad con una mayor esperanza de vida. ${ }^{5}$

Las manifestaciones orales de la ET ocurren en el $11 \%$ de los pacientes, e incluyen hemangiomas, quistes y pseudoquistes en los maxilares, hiperostosis, atrofia alveolar, alteraciones del esmalte. Otras menos frecuentes son la asimetría facial, paladar ojival, úvula bífida, labio leporino y paladar hendido, diastemas y alteraciones en la erupción dentárea. ${ }^{8}$ El propósito de este trabajo es presentar un paciente afecto de ET con manifestaciones faciales e intraorales, quien acudió a nuestro servicio por una lesión radiopaca en la mandíbula que tras su extirpación fue diagnosticada de fibroma desmoplásico y discutir las principales características clínicas, radiológicas, evolutivas y terapéuticas de la enfermedad.

\section{Caso clínico}

Un paciente varón de 33 años fue remitido a consulta por presentar una tumoración en región basal mandibular a nivel parasinfisario del lado derecho de varios años de evolución y lento crecimiento. Entre sus antecedentes médicos destacaba padecer una esclerosis tuberosa y haber sido sometido a un trasplante de riñón tras sufrir una nefrectomía por un angiomiolipoma renal. Presentaba como síntomas de la enfermedad el denominado adenoma sebáceo de Pringle a nivel nasogeniano, hamartomas retinianos en el fondo de ojo y lesiones fibróticas a nivel cervical posterior. En la exploración clínica se apreció un lesión dura y adherida a la man-

\section{Introduction}

Tuberous sclerosis (TS), or Bourneville's disease, is a congenital anomaly of embryonic development that is transmitted by autosomal dominant inheritance and has different forms of clinical expression. It is currently associated with mutations of the tumor growth suppression genes TSC1 and TSC2.' It is classified among the so-called phacomatoses, or developmental anomalies, which can originate tumors and/or hamartomas of the nervous system. 2,3 It is characterized by the formation of benign hamartomatous tumors, neurofibromas, and angiofibromas located in different organs. ${ }^{4}$ The disease occurs in 0.1-0.6\% of people diagnosed as having epilepsy and mental retardation and in 1/30,000-50,000 of the general population. ${ }^{5-8}$ The disease prevalence is 1 out of 6,000 inhabitants. ${ }^{7}$

The classic TS triad is epilepsy, mental retardation, and facial angiofibromas, frequently in the form of butterfly wings. However, the triad is observed in less than one-third of patients. In up to $6 \%$ of cases, none of these symptoms occurs. In incomplete or frustrated forms, the diagnosis may be overlooked, which is why it is important to suspect the disease in patients with epilepsy in addition to skin anomalies and progressive neurologic deterioration. 2, 2,10 Most patients with TS die before the age of 20 years. The cause of death is generally status epilepticus, pneumonia, cachexia, or acute myocardial infarction. Paucisymptomatic or incomplete forms of the disease exist that have a greater life expectancy. ${ }^{5}$

The oral manifestations of TS occur in $11 \%$ of patients and include hemangiomas, maxillary cysts and pseudocysts, hyperostosis, alveolar atrophy, and tooth enamel defects. Less frequent manifestations are facial asymmetry, higharched palate, bifid uvula, cleft lip and cleft palate, diastemata and dental eruption anomalies. ${ }^{8}$ The purpose of this study is to report the case of a patient with TS and facial and intraoral manifestations. The patient was seen in our department for a radiopaque lesion of the jaw that was diagnosed as desmoplastic fibroma when excised. The main clinical, radiologic, evolution, and therapeutic features of the disease are discussed.

\section{Clinical case}

A 33-year-old man was referred for a slow-growing tumor of the right lower parasymphyseal mandibular region of several years evolution. His medical history included tuberous sclerosis and kidney transplantation after nephrectomy for renal angiomyolipoma. His disease symptoms included Pringle's sebaceous adenoma in the nasogenial area, retinal hamartomas, and fibrotic lesions of the posterior cervical area. The clinical examination disclosed a hard lesion adhered to the jaw, approximately $2 \times 2 \mathrm{~cm}$ in diameter, with mild tenderness (Fig. 1A). The skin of the lateral cervi- 
díbula, de un tamaño aproximado de $2 \times 2 \mathrm{~cm}$ de diámetro, con discreto dolor a la palpación (Fig. 1A). En la piel de la región cervical lateral y en la nuca se observaron múltiples pequeñas lesiones excrescentes de coloración oscura y aspecto fibrótico (Fig. 1B). En la exploración intraoral se objetivaba una hiperplasia gingival que se achacó al tratamiento crónico anticonvulsivante con hidantoína para evitar las crisis epilépticas típicas de su síndrome de base y que el paciente había padecido con anterioridad.

En la radiografía panorámica se observó un aumento de densidad ósea a nivel mandibular en región parasinfisiaria, y en la TC una excrescencia ósea de tipo condroide y una erosión de la cortical mandibular a nivel parasinfisario derecho sin componente de masa de tejidos blandos (Fig. 2). El diagnóstico diferencial radiográfico incluyó: ameloblastoma, mixoma odontogéni$\mathrm{co}$, quiste aneurismático, fibroma condromixoide, hemangioma central o granuloma eosinófilo.

Bajo anestesia general y mediante un abordaje cutáneo se realizó la exéresis de la lesión redondeada dura con un margen de seguridad en la mandíbula (Fig. 3). Además se llevó a cabo la exéresis de los fibromas cervicales en el mismo acto quirúrgico mediante láser $\mathrm{CO}_{2}$. Al día siguiente de la intervención el paciente fue dado de alta. Ha sido revisado posteriormente en consultas externas sin presentar hasta el momento ningún signo ni síntoma de recidiva de la lesión mandibular durante tres años (Fig. 4).

El estudio anatomopatológico de la lesión ósea mandibular extirpada informó que se trataba de una lesión formada por fibroblastos en escaso número y un estroma con gran cantidad de colágeno hialinizado. Se observaron espículas óseas en su interior sin ribete osteoide indicativas de la infiltración ósea de la tumoración. La lesión presentaba células fusiformes con núcleos alargados y uniformes con escasas mitosis y sin atipia, que les confería características de benignidad. El estudio concluyó que se trataba de un fibroma desmoplásico (Fig. 5).
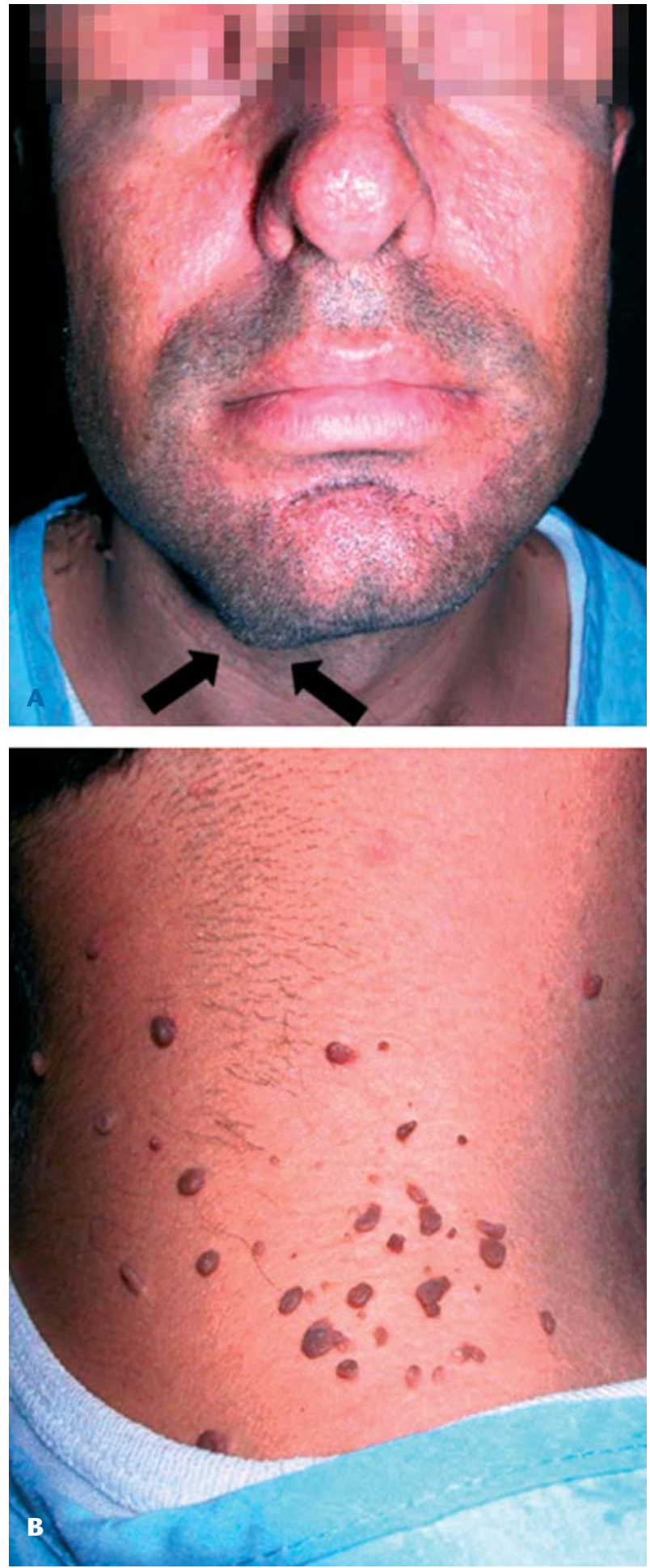

Figura 1. A. Tumoración en la basal mandibular del lado derecho (flechas) y angiofibroma facial en alas de mariposa. B. Detalle de los múltiples fibromas cervicales.

Figure 1. A. Tumor of the right lower jaw (arrows) and butterfly-shaped facial angiofibroma. B. Detail of multiple cervical fibromas. cal region and nape exhibited multiple small, dark-colored excrescent lesions of fibrotic appearance (Fig. 1B). The intraoral examination found gingival hyperplasia that was attributed to chronic anticonvulsant treatment with hydantoin to prevent the epileptic seizures typical of the patient's underlying syndrome.

In the panoramic radiograph, increased bone density was observed in the parasymphyseal region of the jaw. CAT showed a chondroid bone excrescence and erosion of the right mandibular cortex in the parasymphyseal area without any soft-tissue component (Fig. 2). The radiographic differential diagnosis included: ameloblastoma, odontogenic myxoma, aneurysmal cyst, chondromyxoid fibroma, central hemangioma, and eosinophilic granuloma.

Under general anesthesia and via a cutaneous approach, a hard round mass with safety margin was removed from the jaw (Fig. 3). Cervical fibromas were removed by $\mathrm{CO}_{2}$ laser in the same surgical act. The patient was discharged on day after the intervention. During follow-up in the outpatient clinic, he has not presented any sign or symptom of recurrence of the mandibular tumor in three years (Fig. 4).

Histopathologic study of the mandibular bone mass removed disclosed scant fibroblasts in a stroma containing a large amount of hyalinized collagen. Bony spicules without an osteoid border indicative of tumoral bone infiltration were observed inside the mass. The lesion contained spindle cells with long, uniform nuclei, scant mitoses and no atypia, suggesting a benign lesion. The study concluded with a diagnosis of desmoplastic fibroma (Fig. 5). 


\section{Discusión}

La ET es una rara enfermedad facomatosa congénita caracterizada por una alta prevalencia de lesiones hamartomatosas múltiples orofaciales, dermatológicas y neurológicas. En el 50\% de los pacientes afectados de la enfermedad, podemos encontrar antecedentes familiares de la misma, siendo una enfermedad de transmisión hereditaria autosómica dominante con variable expresividad. El diagnóstico de la enfermedad en la edad infantil puede resultar difícil, debido a la existencia de las denominadas formas frustradas de la enfermedad que no van a presentar la tríada clásica descrita por Vogt. ${ }^{11,12}$ Aproximadamente, la mitad de los pacientes afectos de ET presentan alteraciones mentales, siendo la más frecuente de ellas la epilepsia. Pueden encontrarse otras manifestaciones neurológicas como calcificaciones intracraneales en aproximadamente el $50 \%$ de los pacientes, tumores cerebrales como gliomas, glioblastomas o ependinomas, tumores retinianos, cataratas, atrofia óptica, facomas, alteraciones del aprendizaje, retraso mental y autismo. 2,6,9,10 Las lesiones cutáneas incluyen el denominado adenoma sebáceo de Pringle a nivel de nariz y mejillas en alas de mariposa, los característicos fibromas cutáneos, los fibromas ungueales o tumores de Koebnen, las manchas en café con leche o las placas en región lumbar de aspecto de piel de tiburón. La presencia de lesiones cutáneas patognomónicas de

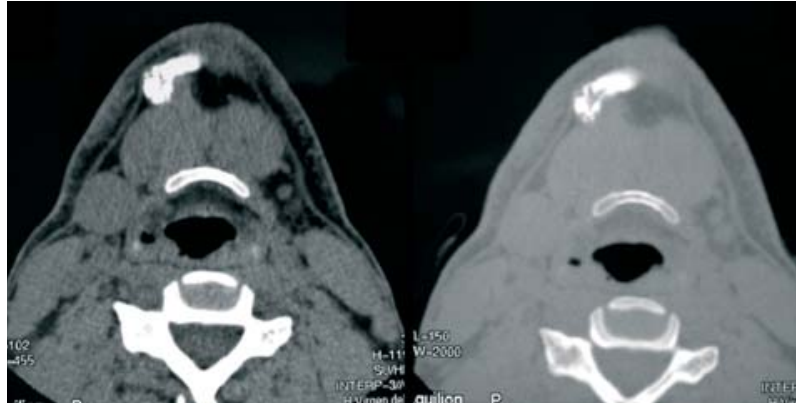

Figura 2. TC axial de mandíbula: lesión mandibular con calcificaciones amorfas tipo condroide.

Figure 2. A. Axial CT of the jaw: mandibular lesion with amorphous, chondroid type calcifications.

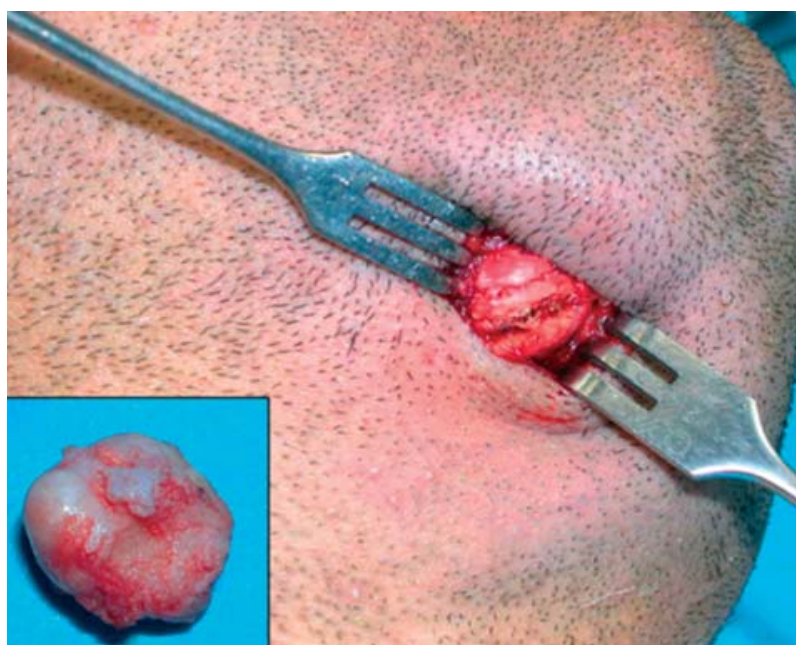

Figura 3. Exéresis de la tumoración con mínima incisión a nivel basal mandibular y detalle pieza quirúrgica.

Figure 3. Excision of the tumor with a minimal incision in the lower jaw and details of the surgical piece.

\section{Discussion}

TS is a rare congenital phacomatous disease characterized by a high prevalence of multiple orofacial, neurologic, and dermatologic hamartomatous lesions. In 50\% of the patients with the disease, there is a family history of the disease, which has an autosomal dominant inheritance with variable expression. Diagnosis of the disease in children can be difficult due to the existence of so-called "frustrated" disease forms that do not display the classic triad described by Vogt. ${ }^{11,12}$ Approximately one half of patients with TS have mental disorders, the most frequent of which is epilepsy. Other neurologic manifestations are observed, such as intracranial calcifications in approximately $50 \%$ of patients, cerebral tumors like glioma, glioblastoma or ependymoma, retinal tumor, cataract, optic atrophy, pha coma, learning disorders, mental retardation, and autism. 2,6,9,10 The skin lesions include Pringle's sebaceous adenoma of the nose and cheeks with a butterfly-wing disposition, typical skin fibromas, ungueal fibromas, or Koeb-

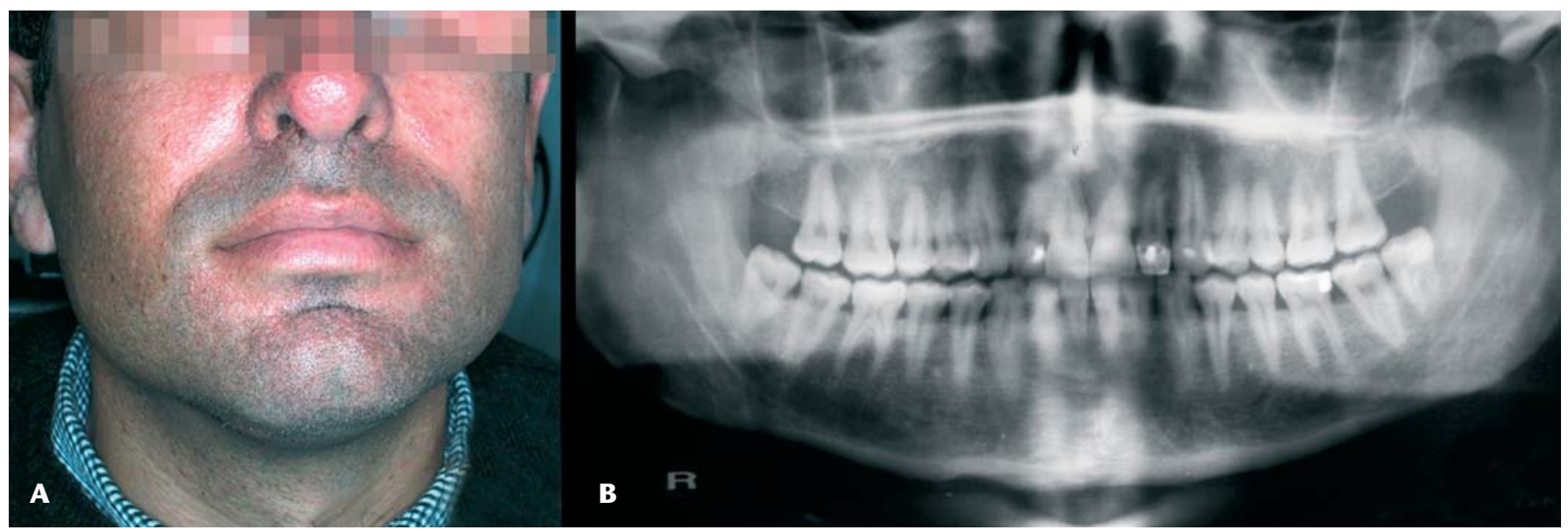

Figura 4. A. Resultado a los 12 meses. B. Radiografía panorámica de control a los 3 años.

Figure 4. A. Result at 12 months. B. Panoramic follow-up radiograph at 3 years. 
la enfermedad puede guiarnos hacia un diagnóstico precoz de la misma, y son además de gran interés pronóstico. Las lesiones cutáneas pueden no estar presentes al nacimiento. ${ }^{2,6,9,10}$ Otras manifestaciones de la ET pueden ser las enfermedades cardíacas entre las que tenemos los rabdomiomas, taquicardia ventricular, obstrucciones valvulares por masas intracardíacas, ${ }^{6}$ fibrosis pulmonar, poliposis intestinal, angiofibromas nasales, astrocitomas y hamartomas retinianos. La enfermedad renal constituye la mayor causa de morbimortalidad de los pacientes afectos de esclerosis tuberosa, $7,8,12$ y consisten en angiomiolipomas renales y quistes e insuficiencia renal crónica.

El diagnóstico generalmente se realiza en la infancia con la aparición de los primeros síntomas neurológicos. El EEG es imprescindible para caracterizar y controlar las crisis epilépticas. Otras pruebas que se realizan son el fondo de ojo, la RM o la TC.2,4 En la tabla 1 se recogen los criterios mayores y menores de diagnóstico de la ET. 8

El tratamiento será específico de cada una de las diferentes manifestaciones clínicas que el paciente presente, siendo completamente sintomático. Es obligatorio llevar a cabo el consejo genético a los familiares de los pacientes afectos. ${ }^{12}$ Cuando se detecta a un niño con la enfermedad, los miembros de la familia deben someterse a los siguientes exámenes: examen dermatológico, fondo de ojo, TC y RM cerebrales y ecografía cardíaca y renal. ${ }^{2}$ La supervivencia por
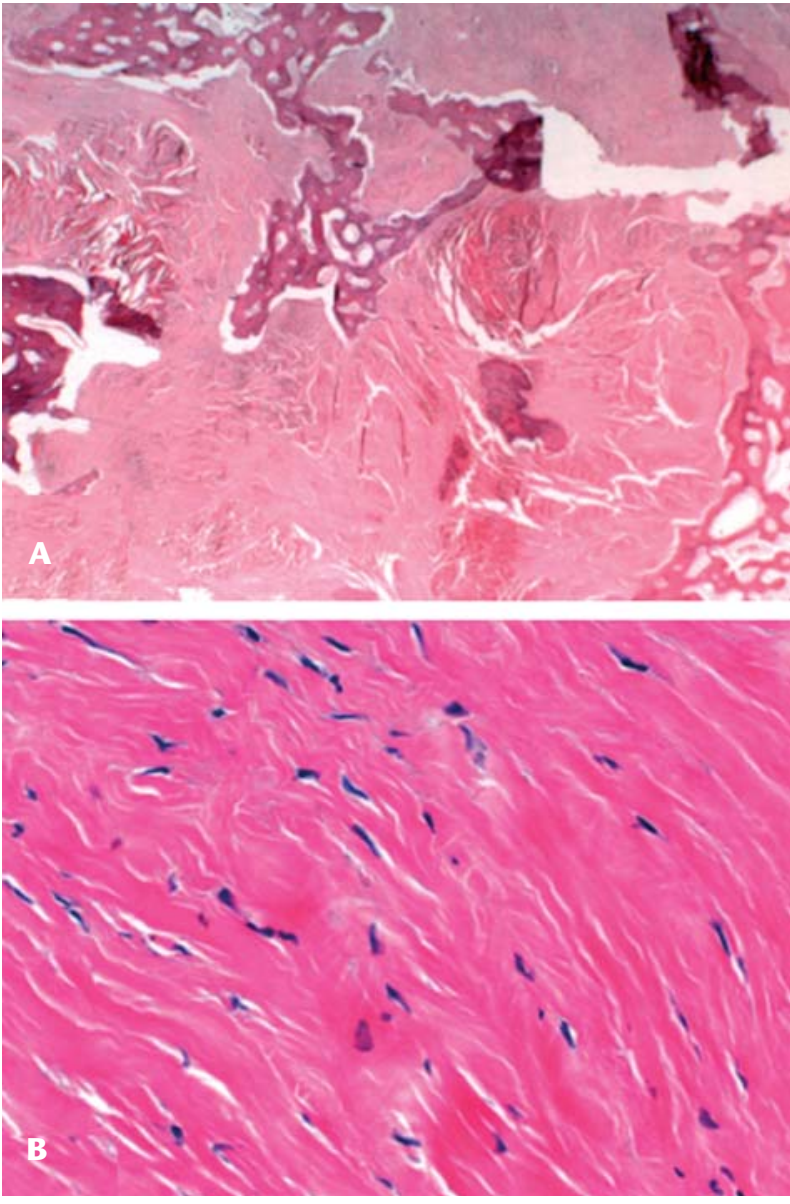

Figura 5. A. Fibroblastos en escaso número, estroma con gran cantidad de colágeno hialinizado y espículas óseas en su interior indicativas de la infiltración ósea de la tumoración. (HE, 4x). B. Células fusiformes con núcleos alargados y uniformes con escasas mitosis y sin atipia. (HE, 20x).

Figure 5. Fibroblastos en escaso número, estroma con gran cantidad de colágeno hialinizado y espículas óseas en su interior indicativas de la infiltración ósea de la tumoración. Scant fibroblasts, stroma containing a large amount of hyalinized collagen and bony spicules indicative of osseous tumor infiltration. (HE, 20x). B. Spindle cells with elongated uniform nuclei with few mitoses and no atypias. (HE, 20x). nen's tumors, café au lait spots, or shagreen plaques in the lumbar region. The presence of the pathognomonic skin lesions can lead to an early diagnosis and has prognostic interest. Skin lesions may not be present at birth. ${ }^{2,6,9,10}$ Other TS manifestations are cardiac disease, including rhabdomyoma, ventricular tachycardia, and valvular obstruction by intracardiac masses, ${ }^{6}$ as well as pulmonary fibrosis, intestinal polyposis, nasal angiofibroma, astrocytoma, and retinal hamartoma. Renal disease is the major cause of morbidity and mortality in patients with tuberous sclerosis $7,8,12$ and consists of renal angiomyolipomas and cysts and chronic renal failure.

The diagnosis is generally made in childhood when the first neurologic symptoms appear. EEG is essential for characterizing and monitoring epileptic seizures. Other studies made are an examination of the ocular fundus, MRI, and CAT.2,4 The major and minor diagnostic criteria of TS are listed in table 1.8 Therapy is specific and symptomatic for each of the patient's clinical manifestations. The patient's family members must be given genetic counseling. ${ }^{12}$ When a nóstico de la enfermedad depende del tipo de crisis cerebrales producidas, de la profundidad de las mismas y del deterioro intelectual que presente el enfermo en la edad adulta. Pero sobre todo, de la aparición de angiomiolipomas renales productores de hemorragia retroperitoneal e insuficiencia renal progresiva que agrava el pronóstico constituyendo la principal causa de muerte en estos pacientes. $2,4,8,9,11,12$

Los trabajos publicados que se ocupan de las manifestaciones orales y maxilofaciales de la ET son escasos. La incidencia de las lesiones orales se sitúa entre el $11 \%$ y el $56 \%$ de los pacientes. Se diagnostican entre los 4 y 10 años o en la pubertad. Incluyen: hiperplasia fibrosa, hemangioma, úvula bífida, labio leporino y fisura palatina, macroglosia, paladar ojival, alteraciones a nivel del esmalte dentario o pérdida de higiene dental atribuible a mala retraso dental. La hiperplasia gingival puede deberse a la terapia anticonvulsivante. ${ }^{3-}$ child with the disease is detected, family members must undergo the following examinations: dermatologic examination, ocular fundus, cerebral CT and MRI, and cardiac and renal ultrasonography. ${ }^{2}$ Survival beyond 30 years is poor. The disease prognosis depends on the type of cerebral seizures that occur, their depth, and the patient's intellectual deterioration as an adult. Above all, the appearance of renal angiomyolipomas that produce retroperitoneal hemorrhage and progressive renal failure aggravates the prognosis, as

Few published studies have addressed the oral and maxillofacial manifestations of TS. The incidence of oral lesions is $11-56 \%$ of patients. They are diagnosed between 4 and 10 years of age or in puberty. They include fibrous hyperthe main cause of death in these patients. 24,4,9,11,12 
6,9,11 Las lesiones en el esmalte afectan principalmente a las caras vestibulares de los incisivos centrales y laterales así como a los caninos. La prevalencia de las lesiones a nivel del esmalte dental está entre el $48 \%$ y el $100 \%$ de los casos según los distintos estudios. Afecta tanto en la dentición temporal como en la definitiva. ${ }^{5,7}$ Existen pocos estudios referentes a las lesiones óseas maxilofaciales en la ET. A nivel maxilar y mandibular se pueden observar lesiones radiopacas denominadas osteítis fibrosa. Otras lesiones descritas son el tumor odontogénico calcificante epitelial, el fibroma desmoplásico, el fibroma odontogénico central o el mixoma odontogénico.4,10,11 Damm y cols., ${ }^{10}$ sugieren que se deberían incluir dentro de los algoritmos de diagnósticos diferenciales de lesiones mandibulares radiográficas, la posibilidad de que estemos ante un caso de ET.

El fibroma desmoplásico es un raro tumor miofibroblástico intraóseo, localmente agresivo, que constituye menos del $1 \%$ de los tumores óseos. De etiología desconocida, su origen se ha relacionado con traumatismos, alteraciones endocrinas o factores genéticos. Fue descrito por primera vez por Jaffe en 1958, siendo Griffith, el que lo describió a nivel mandibular en 1965. Said-Al-Naief y cols., ${ }^{12}$ han revisado en 2006 todos los casos descritos en la literatura, encontrando en los maxilares un total de 74 casos en los últimos 40 años. Miyamoto y cols., ${ }^{3}$ en su revisión de 50 casos, describieron 42 casos mandibulares frente a 8 maxilares. En más del $80 \%$ de los casos aparece en pacientes menores de 30 años, presentando ligeramente predilección por el sexo femenino. Aunque la localización más frecuente sea a nivel maxilar, puede aparecer en otras estructuras óseas tales como fémur, pelvis, radio o tibia. La asociación de fibromas desmoplásicos maxilares a ET es aún más infrecuente. Vargas-González y cols., ${ }^{1}$ reportan un caso en 2004, y hacen referencia a otro caso de Miyamoto y cols., ${ }^{3}$ en 1995, y cuatro casos de Damm y cols., ${ }^{10}$ en 1999.

El fibroma desmoplásico puede ser asintomático en algunos casos, pero se suele presentar como una masa de lento crecimiento, firme, provocando generalmente dolor e inflamación. Otros síntomas que pueden aparecer incluyen pérdidas dentarias, trismus o limitación de la apertura oral, maloclusión, disestesias, hemorragia o infección tumoral, infección, sinusitis recurrentes y exoftalmos. Radiológicamente, aparece normalmente como una lesión bien definida, radiotrasparente o radiopaca, uni o multiloculada, con trabéculas de tejido conectivo en su interior. Podemos observar en plasia, hemangioma, bifid uvula, cleft lip and cleft palate, macroglossia, high arched palate, tooth enamel abnormalities, or poor dental hygiene due to delayed dental eruption. Gingival hyperplasia may occur as a result of anticonvulsant therapy. ${ }^{3-6,9,11}$ Tooth enamel defects affect mainly the vestibular faces of the central and lateral incisors and canines. The prevalence of tooth enamel defects is $48-100 \%$ of cases, depending on the study. Both temporary and permanent teeth are affected. 5,7 There have been few studies of the maxillofacial bone lesions in TS. Radiopaque lesions identified as fibrous osteitis are observed in the maxillary and mandibular bones. Other lesions described are epithelial calcifying odontogenic tumor, desmoplastic fibroma, central odontogenic fibroma, and odontogenic myxoma, 4,10,11 Damm et al. ${ }^{10}$ suggest that TS should be included in the differential diagnosis algorithms of radiographic mandibular lesions.

Desmoplastic fibroma is a rare, locally aggressive, intraosseous myofibroblastic tumor responsible for less than $1 \%$ of bone tumors. It is of unknown etiology, but its origin has been related to trauma, endocrine disorders, and genetic factors. It was first described by Jaffe in 1958. Griffith was the first to describe it in the jaw, in 1965. In 2006, Said-Al-Naief et al. ${ }^{12}$ reviewed all the cases reported in the literature and found a total of 74 cases in the jaw in the last 40 years. Miyamoto et al.,3 in a review of 50 cases, described 42 mandibular versus 8 maxillary cases. In more than $80 \%$ of cases, it occurs in patients under the age of 30 years, with a slight predilection for the female sex. Although the most frequent location is the maxilla, it can appear in other bones, such as the femur, pelvis, radius, or tibia. The association of maxillary desmoplastic fibroma and TS is even more uncommon. Vargas-González et al.1 reported a case in 2004 and cited another case of Miyamoto et al.3 in 1995 and four cases of Damm et al. 10 in 1999. 
muchas ocasiones un adelgazamiento o interrupción de la cortical ósea con afectación de los tejidos blandos. ${ }^{1,12}$

Histológicamente, el fibroma desmoplásico esta constituido por fibroblastos y abundante matriz colágena. A pesar de su naturaleza benigna podemos observar cómo en su interior puede albergar espículas de hueso laminar que ha erosionado, ya que es de crecimiento infiltrativo más que expansivo. El diagnóstico diferencial anatomopatológico se ha de realizar fundamentalmente con la displasia fibrosa (forma hueso, tiene ribete osteoide y el estroma es fibrovascular), con el fibrosarcoma de bajo grado (presenta pleomorfismo nuclear, con abundantes mitosis con atipias) y con el osteosarcoma de bajo grado (el cual va a formar hueso presentando ribete osteoblástico en su estructura).

El tratamiento de elección del fibroma desmoplásico continúa siendo controvertido. Jaffe recomienda como tratamiento de elección la resección segmentaria cuando la lesión muestra signo de agresividad con afectación de partes blandas. También se ha aceptado como primer tratamiento el curetaje de la lesión aunque con mayor tasa de recidiva. 3,12 Sugiura, ${ }^{3}$ indica que el tratamiento de elección del fibroma desmoplásico sería un curetaje seguido de un relleno de la cavidad residual con injerto de hueso autólogo, con un porcentaje de recidiva del $24 \%$. Eisen y Butler, 1,3 recomiendan realizar un tratamiento conservador de la lesión en las áreas faciales para así evitar posibles deformaciones, aunque si se ha producido infiltración de los tejidos blandos por parte del tumor es necesario realizar resección tumoral. Debido al potencial de recidiva del fibroma desmoplásico, el periodo de seguimiento recomendado tras la cirugía es de tres años.

El diagnóstico diferencial radiográfico incluye lesiones tales como: ameloblastoma, mixoma odontogénico, tumor odontogénico epitelial calcificante, quiste aneurismático, fibroma condromixoide, hemangioma central, granuloma eosinófilo o sarcomas. El tumor odontogénico epitelial calcificante es uno de los considerados tumores odontogénicos benignos. Más frecuente en varones, a nivel mandibular, presenta predilección por aparecer en la región de los premolares y molares. Su crecimiento es relativamente lento por expansión. El tratamiento consiste en la enucleación y curetaje agresivo de la cavidad residual, aunque se han observado recurrencias. ${ }^{13} \mathrm{EI}$ mixoma odontogénico es un tumor benigno aunque localmente agresivo. Constituye el 3-8\% de los tumores odontogénicos, presentándose en el $60 \%$ de los casos en la segunda o tercera década de la vida. Es más frecuente que se localice a nivel de la mandíbula sobre todo a nivel del ángulo mandibular o la rama ascendente. El tratamiento quirúrgico sigue siendo de elección. ${ }^{14} \mathrm{El}$ fibroma central odontogénico es tumor benigno que aparece exclusivamente a nivel maxilar. Se localiza generalmente anterior al primer molar. Radiográficamente la lesión está bien definida, bordes escleróticos, pudiendo ser uni o multiloculares, tras la exéresis no suele recidivar. ${ }^{15}$

\section{Conclusiones}

El fibroma desmoplásico es un raro tumor fibroso óseo localmente agresivo de lento crecimiento muy rara vez asociado a la ET.
Desmoplastic fibroma may be asymptomatic in some cases, but it usually occurs as a firm, slow-growing mass that generally causes pain and inflammation. Other symptoms that can appear include dental loss, trismus, or restricted mouth opening, malocclusion, dysesthesia, tumoral hemorrhage or infection, infection, recurrent sinusitis, and exophthalmos. Radiologically, it usually manifests as a well defined, radiolucent or radiopaque unilocular or multilocular lesion containing connective tissue trabeculae. We can often observe thinning or interruption of the bone cortex with soft tissue involvement. 1,12

Histologically, desmoplastic fibroma is constituted by fibroblasts and abundant collagen matrix. Despite its benign nature, it may contain spicules of eroded laminar bone because its growth is more infiltrative than expansive. The histopathologic differential diagnosis must be made fundamentally with fibrous dysplasia (bone formation, osteoid rim, and fibrovascular stroma present), low-grade fibrosarcoma (nuclear pleomorphism with abundant mitoses and atypias present), and low-grade osteosarcoma (osteoformation and an osteoblastic rim).

The treatment of choice of desmoplastic fibroma is still debated. Jaffe recommends segmental resection as the treatment of choice when the lesion shows signs of aggressiveness and soft-tissue involvement. Curettage of the lesion is accepted as the first treatment, although it has a higher recurrence rate. ${ }^{3,12}$ Sugiura 3 claims that the treatment of choice of desmoplastic fibroma is curettage followed by filling of the residual cavity with autologous bone graft, which has a recurrence rate of $24 \%$. Eisen and Butler 1,3 recommend conservative treatment of facial lesions to avoid deformation, but tumor resection if soft-tissue infiltration by the tumor has occurred. Due to the recurrence potential of desmoplastic fibroma, the recommended postoperative follow-up period is three years.

The radiographic differential diagnosis includes lesions such as ameloblastoma, odontogenic myxoma, epithelial calcifying odontogenic tumor, aneurysmal cyst, chondromyxoid fibroma, central hemangioma, eosinophilic granuloma, and sarcoma. Epithelial calcifying odontogenic tumor is one of the odontogenic tumors considered benign. It is more common in men and in the jaw it shows predilection for the premolar and molar region. Its growth is expansive and relatively slow. Treatment consists of enucleation and aggressive curettage of the residual cavity, although recurrence has been observed..$^{13}$ Odontogenic myxoma is a benign, but locally aggressive, tumor. It constitutes 3-8\% of odontogenic tumors, occurring in $60 \%$ of cases in the second or third decade of life. It is most frequently located in the jaw, particularly in the mandibular angle or ascendant ramus. Surgery is the treatment of choice. ${ }^{14}$ Central odontogenic fibroma is a benign tumor that occurs only in the maxilla. It is generally located anterior to the first molar. Radiographically, the lesion is well defined, has sclerotic margins, and may be unilocular or multilocular. It usually does not recur after exeresis. ${ }^{15}$ 
El diagnóstico se ha de realizar mediante la clínica y el estudio radiográfico, observándose como una lesión relativamente bien definida, radiopaca, uni o multiloculada, siendo la confirmación diagnóstica llevada a cabo por el estudio anatomopatológico del tumor extirpado. El tratamiento más aceptado para los fibromas desmoplásicos maxilares es la resección de la tumoración con amplios márgenes de seguridad para evitar la recidiva; en nuestro caso el tratamiento fue definitivo.

\section{Bibliografía}

1. Vargas-Gonzalez R, San Martin-Brieke W, Gil-Orduna C, Lara-Hernandez F. Desmoplastic fibroma-like tumor of maxillofacial region associated with tuberous sclerosis. Pathol Oncol Res 2004;10:237-9.

2. López López J, Rodríguez de Rivera E, Márques Osares M, Finestres Zubeldia F, Chimenos Küstner E, Roselló Llabrés X. Esclerosis tuberosa y manifestaciones orales. Caso clínico. Med Oral 2004;9:216-23.

3. Miyamoto Y, Satomura K, Rikimaru K, Hayashi Y. Desmoplastic fibroma of the mandible associated with tuberous sclerosis. J Oral Pathol Med 1995;24:93-6.

4. López E, Escovich L, Vigna A. Esclerosis tuberosa: Presentación de un caso clínico con manifestaciones estomatológicas. Med Oral 2003;8:122-8.

5. Murti PR, Bhonsle RB, Mehta F, Daftary DK. Oro-facial lesions of tuberous sclerosis. Int J Oral Surg 1980;9:292-7.

6. Scully C. Oral mucosal lesions in association with epilepsy and cutaneous lesions: The Pringle- Bourneville syndrome. Int J Oral Surg 1981;10:68-72.

7. Cutando A, Gil JA, López J. Oral health management implications in patients with tuberous sclerosis. Oral Surg Oral Med Oral Pathol Oral Radiol Endod 2000; 89:430-5.

8. Barron RP, Kainulainen VT, Forrest CR, Krafchik B, Mock D, Sandor GKB. Tuberous sclerosis: clinicopathologic features and review of the literature. J Craniomaxilofac Surg 2002;30:361-6.

9. Scully C. Orofacial manifestations in tuberous sclerosis. Oral Surg 1977;44:70616.

10. Damm D, Tomich C, Wite D, Drummond J. Intraosseous fibrous lesions of the jaws, a manifestations of tuberous sclerosis. Oral Surg Oral Med Oral Pathol Oral Radiol Endod 1999;87:334-40.

11. Celenk P, Alkan A, Canger M, Günhan Ö. Fibrolipomatous hamartomas in a patient with tuberous sclerosis: Report of a case. Oral Surg Oral Med Oral Pathol Oral Radiol Endod 2005;99:202-6.

12. Said-Al-Naief N, Fernandes R, Louis P, Bell W, Siegal G. Desmoplastic fibroma of the jaw: A case report and review of literature. Oral Surg Oral Med Oral Pathol Oral Radiol Endod 2006;101:82-94.

13. Rubin M, Delgado E, Cozzi G, Palladino V. Tuberous sclerosis complex and a calcifying epithelial odontogenic tumor of the mandible. Oral Surg Oral Med Oral Pathol 1987;64:207-11.

14. Harrison MG, O’Neill ID, Chadwick BL. Odontogenic myxoma in an adolescent with tuberous esclerosis: A case report. J Oral Pathol Med 1997;26:339-41.

15. Swarnkar A, Jungreis C, Peel RL. Central odontogenic fibroma an intracraneal aneurysm associated with tuberous sclerosis. Am J Otolaryngol 1998;19:66-9.

\section{Conclusions}

Desmoplastic fibroma is a rare, locally aggressive, slowgrowing fibrous bone tumor that rarely is associated with TS. The diagnosis is based on the clinical manifestations and radiographic study, where it is observed as a relatively well defined, radiopaque, and unilocular or multilocular lesion. Diagnostic confirmation is by histopathologic study of the excised tumor. The most accepted treatment for desmoplastic fibroma of the jaw is resection of the tumor with ample safety margins to prevent recurrence. In our case, the treatment was definitive. 